\title{
Social loafing in student entrepreneurship teams
}

\author{
Roisin Lyons, Dublin City University \\ Dr. Theodore Lynn, Dublin City University \\ Dr. Ciarán Mac an Bhaird, Dublin City University
}

\subsection{Abstract}

As a form of collaborative learning, allowing students to engage in teamwork has been attributed to the retention of information, motivation, critical reasoning, communication and social skills among others (Hansen 2006). However, is the use of teamwork always the right technique? The benefits outlined are dependent on the success of the teamwork initiative which is not guaranteed (Holtham et al. 2006; Eva 2002). Ineffective student teams can experience numerous problems including role confusion, low trust, clashing personalities and the social loafing phenomenon, where certain members of the group do not participate fully (Burdett, 2003; Hansen, 2006). Researchers have attempted to prevent such problems using pedagogical interventions with varying degrees of success (Pieterse \& Thompson 2010; Hardy \& Crace 1997). The team signatory code is among these tactics considered, a governance document whereby teams create their own code of conduct for the teamwork initiative (Bailey et al. 2005). This research study proposes that the use of the team signatory code could assist to facilitate teamwork on two levels; firstly by acting as an early development tool for teams during their norming stages of functioning, and secondly as an earlywarning system for educators to detect poorly developing teams.

This research paper examines teams within the context of entrepreneurship education or EE, particularly focusing the team problem of social loafing. While teamwork is a common element of most deliveries of entrepreneurship education (Hytti \& O'Gorman 2004), there are few studies which explore the actual impact of the team on performance in this context. In entrepreneurship more generally it has been found that team-level variables has an impact on team effectiveness (Hill et al. 2013) however studies like these are limited in the field of entrepreneurship education. As team-led entrepreneurship is gaining both academic and wider interest, as seen in the review by Klotz et al. 
(2014), the teamwork dynamic in an educational setting of entrepreneurship may have discrete characteristics, warranting its own research inquiry.

This paper assesses the level of social loafing which occurs in an entrepreneurship education context, using a sample of 310 student teams from an Irish University. We begin by reviewing the literature relating to teamwork and social loafing, orienting this around the lens of the collective effort model. We then discuss the team signatory code as a pedagogical tool in the early development of team functioning and propose a number of hypotheses relating to its use. Lastly we describe the methodology of our empirical studies which attempt to investigate the benefit of the use of the team signatory code in an entrepreneurship educational context and present our research findings and conclusions. In view of these investigations, the paper makes a number of important contributions to the current EE literature. First, we add to the growing body of knowledge surrounding teamwork in EE. Secondly we offer findings that support the use of the team-signatory code to detect poorly performing teams in the context of EE.

\subsection{Literature Review}

\subsection{Teamwork as a pedagogical approach}

At its core, a team consists of two or more individuals interacting with one another to accomplish a shared objective (Salas et al. 1992; Woodcock \& Francis 1981). The ambition in teamwork is that by integrating more than one individuals' skillset and knowledge, the resulting process and output will be enhanced synergistically. Teamwork is an important tool in business used to enhance productivity (Beal et al. 2003), deal with complex problems, make collective decisions (Knight, Durham and Locke, 2001) and allow businesses to remain competitive (English et al. 2004). Thus employers have been making consistent and repeated calls for well-rounded graduates displaying communication, problem-solving and teamwork skills; all which could be aided by effective teamwork activities in higher education (Hernandez 2002; Dunne \& Rawlins 2000). Consequentially, research into group and teamwork has gained much attention in the field of education, considering teamwork as a collaborative and cooperative approach to learning. Rather than working in a competitive or individualistic environment, students are welcomed to share skills and information with each other in 
a collaborative and interactive setting (Laal \& Ghodsi 2012). Collaborative and cooperative learning has been well-documented in terms of student benefits (see Table 1.0). In their meta-analysis, Johnson, Johnson and Stanne (2000) investigated 164 studies of collaborative learning using 8 different learning models, finding all eight to have significantly higher student achievement rates than competitive or individualistic approaches. There is an expansive spectrum of activities which are thought by educators to fit under the umbrella term of collaborative learning, the most commonly used is teamwork. Generally speaking, students are placed into teams of 4-8 who meet at intervals during term, both in class and outside class times to work together, usually on a single project, producing deliverables for grading at the conclusion (Druskat \& Kayes 2000).

\begin{tabular}{|c|c|c|}
\hline Category & Reported benefit to students & Authors \\
\hline $\begin{array}{l}\text { Psychological } \\
\text { benefits }\end{array}$ & $\begin{array}{l}\text { Increases academic self-esteem; increases } \\
\text { motivation; increases student satisfaction; } \\
\text { reduces anxiety among students; develops } \\
\text { trust and a positive attitude toward educators; } \\
\text { increased social responsibility }\end{array}$ & $\begin{array}{l}\text { (Hytti et al. 2010; Oakley et } \\
\text { al. 2004; Johnson \& Johnson } \\
\text { 1989; Gillies 2004; Panitz } \\
\text { 1999) }\end{array}$ \\
\hline $\begin{array}{l}\text { Academic } \\
\text { benefits }\end{array}$ & $\begin{array}{l}\text { Enhanced critical thinking and problem } \\
\text { solving, enhanced cognitive learning and } \\
\text { retention, enhanced student learning; } \\
\text { enhanced student achievement; increased } \\
\text { student attendance; increased student } \\
\text { engagement with academic content; enhanced } \\
\text { ability to recognise errors. }\end{array}$ & $\begin{array}{l}\text { (Steinbrink \& Jones 1993; } \\
\text { Terenzini et al. 2001; Nowak } \\
\text { et al. 1996; Veenman et al. } \\
\text { 2002; Cook 1991; Qin et al. } \\
\text { 1995) }\end{array}$ \\
\hline
\end{tabular}

Table 1.0 Benefits of collaborative learning (Adapted from Laal and Ghodsi, 2012)

\subsection{Entrepreneurship Education and Teamwork in EE}

Emerging in US business schools during the 1960's and 1970's, the training for and of entrepreneurship has spread exponentially and internationally ever since (Carey \& Matlay 2011; Fiet 2001; Fleming 1999; Solomon et al. 1994). The link between entrepreneurship education and new venture creation has been witnessed many times (Matlay, 2006a; Shane, 2004; McMullan, Chrisman \& Vesper, 2002; Varela \& Jiminez, 2001) As a result, entrepreneurship education is now a widely popular aspect of many business school programmes with a growth in both voluntary and obligatory courses (Rasmussen \& Sørheim 2006). Yet in order to sustain engagement by Higher Education in its development, this needs to be proven definitively and repeatedly by accepted means (O'Conner et al., 2012). Taking a general sense, entrepreneurship education is defined by Heinonen \& Poikkijoki (2006, p.81) as 'activities aimed at developing enterprising or entrepreneurial people and increasing 
their understanding and knowledge about enterprise and entrepreneurship'. Though this definition establishes the main purpose of entrepreneurship education, many researchers believe that its impact is wider, affecting the skill-set and knowledge beyond entrepreneurship itself to benefit individuals in any innovative context (Lewis K. \& Massey C. 2003; Hynes 1996). Fayolle, Gailly \& Lassas-Clerc (2006, p.702) defines an entrepreneurship education programme:

'Any pedagogical programme or process of education for entrepreneurial attitudes and skills, which involves developing certain personal qualities. It is therefore not exclusively focused on the immediate creation of new businesses'

There is a research consensus that enterprise and entrepreneurship education are valuable additions to many business and non-business disciplines (Bosma \& Levie, 2010; Rae, 2010; Hynes, 1996). Benefits include helping to integrate various business subjects and topics; promoting cooperation and knowledge transfer between educational institutes and business, and improved decision making in students (Faoite et al., 2003). Aspects included in a typical enterprise education course or module include idea generation, market research, product and process development, communication, negotiation, conflict management, project management and people management (Birdthistle et al. 2007). Recently, amid calls for more experiential approaches to the teaching of entrepreneurship education, authors in the field have begun to focus on teaching elements including action learning (Rasmussen \& Sørheim 2006; Hytti \& O’Gorman 2004), career-orientation (Rae 2007), interdisciplinary teams (Lüthje \& Prügl 2006), competencies (Mojab et al. 2011) and learner-centric approaches (Jones 2006). While these all help the subject to evolve, the most popularly reported pedagogical practices employed remain to be the use of business plans and teamwork (Hytti \& O'Gorman 2004). Yet there have been few studies which look at the impact of the team on the individual student or the output in this context. These studies have some contrasting viewpoints on the effectiveness of teamwork on the individual student. For example, Hynes (1996) suggests that teamwork in entrepreneurial education can aid skill development and help build a culture of enterprise and learning. Hamidi et al. (2008) notes that teamwork in EE may allow for a greater development of creativity in students. In a very recent study, Harms (in press) found that team learning behaviours 
positively affected group performance in an EE setting and propose the delivery of team learning training to entrepreneurial students. Contrary to these positive findings, Wing Yan Man and Wai Mui $\mathrm{Yu}, 2007$ did not find a relationship between team interaction and individual student competency development. This particular study however, was set amongst younger school students in Hong Kong and results were thought to have been skewed by the culture of didactic teaching rather than teamwork/active learning that is in existence in that region. Canziani et al. (2015) found weak empirical indications that the use of teamwork in entrepreneurship education led to lower achievement orientation in students than courses that did not deploy teamwork.

\subsection{Unequal workloads in student teams; the social loafing phenomenon}

'Becoming part of an ineffective or dysfunctional team may well be inferior to independent study in promoting learning and can lead to extreme frustration and resentment'(Oakley et al. 2004, p.9).

As outlined previously, teamwork is much advocated in education, however teamwork can be problematic for the students and educators involved when it is not functioning correctly. Problems experienced by teams in an educational setting can be numerous and of varying intensity; ranging from minor issues such as scheduling difficulties and miscommunications to larger challenges such as the poor attendance of members, lack of leadership, personality clashes, lack of trust and confusion of team roles (Hansen 2006; Burdett 2003; Baldwin et al. 1997). In particular, the reduced or nonparticipation of certain members in a team is a prevalent predicament in student environments and is known as social loafing (Dommeyer 2007).

Social loafing or 'free-riding' in team and student team contexts is demonstrated by a reduction in effort by an individual working in a group (Gagne \& Zuckerman 1999). It is defined by Aggarwal and O'Brien (2008, p.256) as 'a behavioural pattern wherein an individual working in a group setting fails to contribute his or her fair share to a group effort as perceived by group members'. The origins of research into social loafing came from an unpublished work in 1913 depicting the 'Ringlemann effect', a phenomenon where the efficiency of the completion of a group task is less than the sum of each individual's contribution (Latane, Williams, \& Harkins, 1979) . Latane et al. (1979) explain this anomaly by suggesting that social pressure to complete a task is 
distributed when in a group, resulting in each individual feeling reduced pressure to contribute. In a student team, this is exhibited by certain members being repeatedly absent, being disengaged and fulfilling their work commitments inadequately or not at all.

In line with this phenomenon, other related concepts were drawn from social loafing. Its reverse, as termed by Pieterse and Thompson (2010) is the 'diligent isolate', which refers to an individual who will work conscientiously, doing more than his or her fair share in order to compensate for less productive members to reach task completion. The concept, known as social facilitation refers to 'an increase in effort by a person working in a group' (Gagne and Zuckerman 1999, p.525). This individual while attempting to salvage the project may be detrimental to the group by restricting the development of other members' skill or knowledge sets. Such an individual may be better academically than other members, or may believe themselves to be. 'Retributive loafing' occurs when a student reduces his/her work input when others are free-riding because he/she does not want to be taken advantage of (Jackson \& Harkins 1985).

\subsection{The Collective Effort Model for teamwork}

Used in studies regarding social loafing in the past, the expectancy-value theory was devised by Vroom (1964) to account for individual motivation to complete a task (Karau \& Williams 1993; McMullen \& Shepherd 2006). The theory suggests that individuals are motivated by three main factors: value, expectancy and instrumentality. Depending on the extent of these three factors, the individual will be motivated to perform.

- Value: The perceived benefit that is gained by the completion of the task will support the motivation to perform.

- Expectancy: The extent to which an individual believes their input will affect their performance.

- Instrumentality: The extent to which an individual believes their performance will affect the outcome. 
To move this theory into the collective, Karau and Williams $(1993 ; 2001)$ devised the Collective Effort Model (CEM) and in doing so broadened much of the theory (See Figure 1.0). Focusing on instrumentality, they prescribed three factors that influence the level of expectancy felt by an individual in a group. These relates to the perceived relationship between individual performance and group performance, between group performance and group output and lastly, the perceived relationship between group outcomes and individual outcomes. While Karau and Williams (1993) accept that some individual outcomes may not be tangible, this model focuses mainly on performance outcomes. Team performance relates to the degree that team output meets or exceeds the performance standards given by supervisors or customers within or outside the organisation' (Antoni \& Hertel 2009, p.255) This is sometimes criticised as it is a result and does not consider the impediments (externally) that can influence output despite the behaviour of the team. The CEM made a number of predictions in line with their model in terms of social loafing. These have been tested and inferred in many studies relating to social loafing and will be discussed in the next section. If a team member believes that this perceived pathway is skewed or weakened in any way or if he/she thinks that increased effort will not result in a proportional benefit, the individual may reduce his/her effort in the collective task and engage in social loafing. While Vroom's theory is central to the CEM, it is in agreement with many of the other explanatory theories in the area as seen in Table 2.0. In fact Karau and Williams (1995, p.135) welcome these other theories they each also deepen our understanding of the concept of social loafing and inspires other avenues of research.

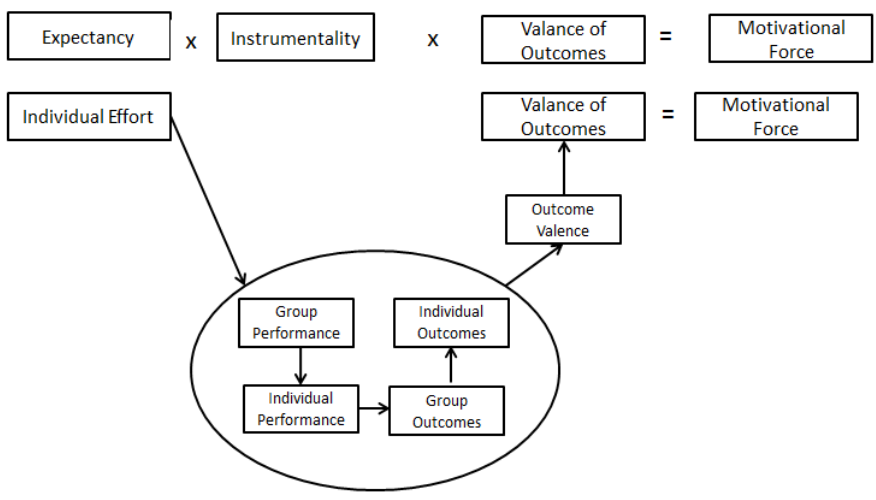

Figure 1.0: The Collective Effort Model (Adapted from Karau and Williams, 1993) 


\begin{tabular}{|c|c|c|c|c|}
\hline Theory & Proposition & $\begin{array}{l}\text { Application to CEM } \\
\text { Model }\end{array}$ & Other Research in the Area & \\
\hline $\begin{array}{l}\text { Social Impact } \\
\text { Theory } \\
\text { (Latané 1981) }\end{array}$ & $\begin{array}{l}\text { The impact of an } \\
\text { external influence (e.g. } \\
\text { manager/teacher) is } \\
\text { diluted in terms of } \\
\text { strength, immediacy and } \\
\text { targets present when in a } \\
\text { group leading to a } \\
\text { reduced effort per } \\
\text { additional member. }\end{array}$ & $\begin{array}{l}\text { There is a stronger } \\
\text { perceived contingency } \\
\text { between individual effort } \\
\text { and valued outcomes } \\
\text { when working in a } \\
\text { smaller group }\end{array}$ & $\begin{array}{l}\text { Students are more productive in smaller groups as they } \\
\text { are more cohesive and fewer problems develop. } \\
\text { In smaller groups, individuals put forward an increased } \\
\text { quantity and quality of work } \\
\text { Teams should be limited to five or under members to } \\
\text { reduce incidences of social loafing. } \\
\text { There is an acceptable range from } 2 \text { to } 10 \text { members, } \\
\text { and any number within this range will not affect team } \\
\text { performance significantly. } \\
\text { The ideal number of members in a team depends on } \\
\text { the context and the project itself. }\end{array}$ & $\begin{array}{l}\text { (Wheelan, 2009) } \\
\text { (Chidambaram \& } \\
\text { Tung 2005) } \\
\text { (North, Linley, \& } \\
\text { Hargreaves, 2000); } \\
\text { Pieterse \& } \\
\text { Thompson, 2010; } \\
\text { Deeter-Schmelz et } \\
\text { al., 2002) } \\
\text { (Steiner 1972) }\end{array}$ \\
\hline
\end{tabular}




\begin{tabular}{|c|c|c|c|c|}
\hline $\begin{array}{l}\text { Dispensability of } \\
\text { Effort } \\
\text { (Kerr 1983) }\end{array}$ & $\begin{array}{l}\text { Social loafing is reduced } \\
\text { when individuals believe } \\
\text { their input is unique }\end{array}$ & $\begin{array}{l}\text { If an individual believes } \\
\text { their contribution is } \\
\text { redundant it will affect } \\
\text { their perceived } \\
\text { instrumentality in the } \\
\text { group. }\end{array}$ & $\begin{array}{l}\text { Students who shared a judgement-making task with } \\
\text { other members felt more dispensable than students } \\
\text { working alone or in pairs causing them to increase } \\
\text { their levels of social loafing }\end{array}$ & $\begin{array}{l}\text { (Weldon \& Mustari } \\
\text { 1988) }\end{array}$ \\
\hline \multirow[t]{2}{*}{$\begin{array}{l}\text { Arousal Reduction } \\
\text { (Harkins \& } \\
\text { Szymanski 1989) }\end{array}$} & $\begin{array}{l}\text { Social loafing is reduced } \\
\text { when the task is } \\
\text { meaningful or interesting }\end{array}$ & $\begin{array}{l}\text { If the task is meaningful } \\
\text { it relates to the value } \\
\text { aspect, in that the } \\
\text { individual will feel the } \\
\text { benefit inherent in } \\
\text { completing the task is } \\
\text { worth it. }\end{array}$ & $\begin{array}{l}\text { A group task which is challenging may motivate the } \\
\text { individual to contribute, despite the possibility that } \\
\text { he/she may not be credited for the efforts. }\end{array}$ & $\begin{array}{l}\text { (Harkins \& } \\
\text { Petty,1982) }\end{array}$ \\
\hline & $\begin{array}{l}\text { Social loafing is reduced } \\
\text { when individuals work } \\
\text { with those they respect } \\
\text { (group value) }\end{array}$ & $\begin{array}{l}\text { Relating to the value } \\
\text { aspect of the collective } \\
\text { effort model (CEM) } \\
\text { again, if a person } \\
\text { respects his team } \\
\text { members then supporting } \\
\text { them is a beneficial } \\
\text { outcome in itself (Rutte } \\
\text { 2005). }\end{array}$ & $\begin{array}{l}\text { Cohesion significantly affects the amount of social } \\
\text { loafing present in a team, with the level of loafing } \\
\text { reduced with increased bonding between members. } \\
\text { Cohesion can be improved when the group members } \\
\text { are aligned in academic ability, skill-sets and/or goals. } \\
\text { They suggest that an unaligned group can lead to } \\
\text { frustration between members and may cause greater } \\
\text { social loafing to occur. } \\
\text { There are specific team-level variables that can } \\
\text { compensate for the process effects of social loafing. } \\
\text { Specifically when there are levels of agreeableness and } \\
\text { conscientiousness present in a team, it will counteract } \\
\text { and affect the influence that social loafing has on } \\
\text { performance. }\end{array}$ & $\begin{array}{l}\text { (Karau and } \\
\text { Williams, 1993) } \\
\text { (Pieterse and } \\
\text { Thompson, 2010) } \\
\\
\text { (Schippers, 2014) }\end{array}$ \\
\hline $\begin{array}{l}\text { Self-Efficacy } \\
\text { (Sanna 1992) }\end{array}$ & $\begin{array}{l}\text { Social loafing is reduced } \\
\text { when the individual } \\
\text { believes that he/she has } \\
\text { the capacity to complete } \\
\text { the task well. }\end{array}$ & $\begin{array}{l}\text { If an individual expects } \\
\text { that they can complete } \\
\text { the task to a high } \\
\text { standard they will work } \\
\text { harder as their } \\
\text { expectation of the } \\
\text { outcome (individual }\end{array}$ & $\begin{array}{l}\text { Evidence supported the rationale that self-efficacy had } \\
\text { a mediating effect on performance in group settings. } \\
\text { Collective efficacy was positively correlated to group } \\
\text { performance, and had an effect on the level of } \\
\text { perceived social loafing of the teams tested. }\end{array}$ & $\begin{array}{l}\text { (Sanna 1992) } \\
\text { (Mulvey \& Klein } \\
\text { 1998) }\end{array}$ \\
\hline
\end{tabular}




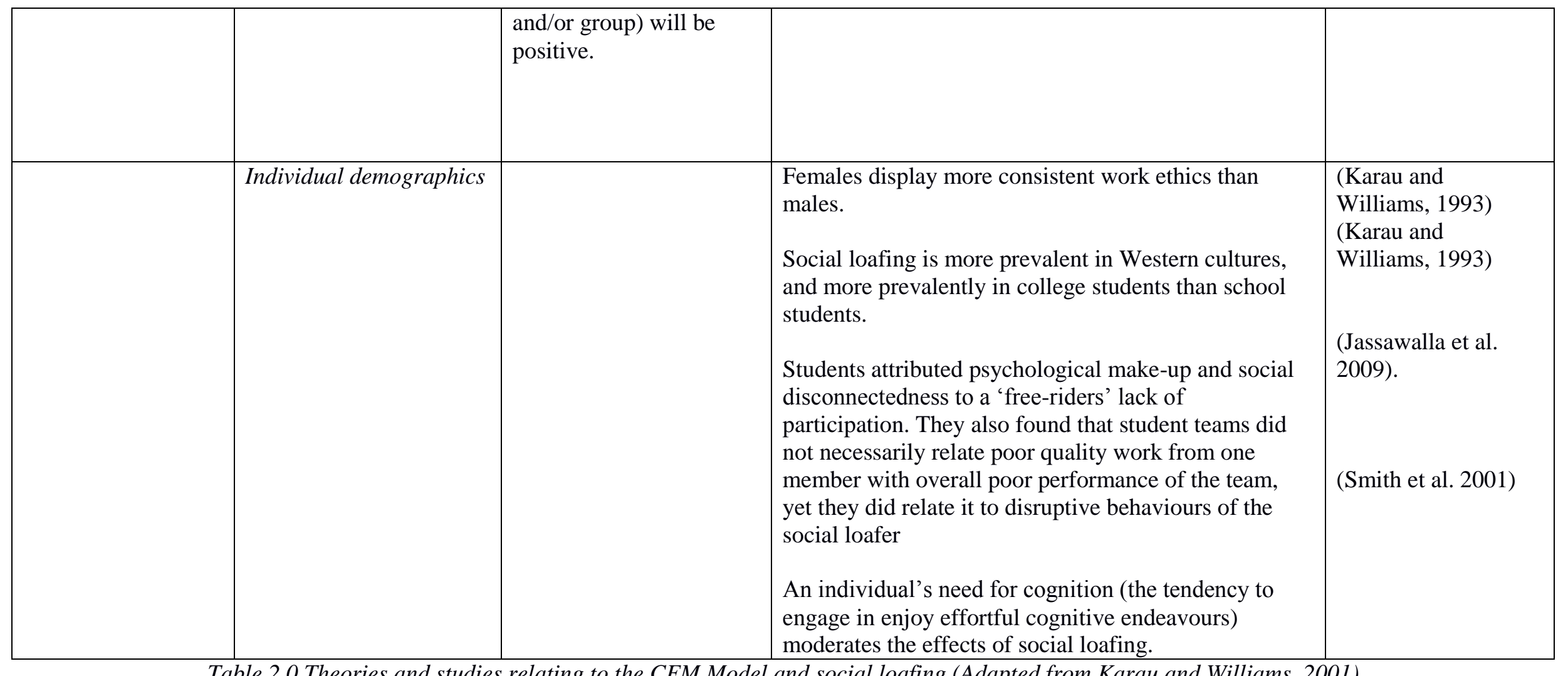

Table 2.0 Theories and studies relating to the CEM Model and social loafing (Adapted from Karau and Williams, 2001) 


\subsection{Combatting Social Loafing: The Team Signatory Code}

Referring to the propositions discussed within Table 2.0, it would seem that teams loaf less when (1) there is a method of evaluating the individual, (2) when teams have fewer members, (3) when members have specific and challenging tasks or (4) ownership of an element of the team task and (5) when team members respect each other. Drawing the majority of these elements together, this research paper proposes that an artefact known as a 'team signatory code' could be an important pedagogical aid to initiate the development of some of these ideals. The team signatory code, a subset of the team charter is among these pedagogical interventions used at the early stage of team development. A team signatory code is a team generated device that stipulates rules used to determine whether individual team members can or cannot receive credit for assignments' (Bailey et al. 2005, p.45). With a team signatory code, teams create their own code of practice dictating the conditions by which they must function, and stipulating the consequences for non-compliance of these conditions. It is used to acknowledge the initiation of teamwork and allows a team define itself and its shared responsibilities. It also 'recognises the delegation of authority from the professor to the students as a cooperative unit' (Valenti et al. 2005, p.5). Essentially it puts the onus on the team unit to develop their own norms and to solve internal problems that may hinder efficiency.

The early creation of the team charter or contract to facilitate the early phases of development is recommended to facilitate close and respectful relationships in teams (Schippers 2014; Cox et al. 2005; Cox \& Bobrowski 2000). Past research has shown the team signatory code is well received by students who find it useful in dealing with early stage social loafing (Bailey et al. 2005) and to facilitate improved team performance (Hunsaker et al. 2011; Cox \& Bobrowski 2000). This is supported by a recent study by Harms (in press) who found that team learning behaviours positively affected group performance in an EE setting and proposed the delivery of team learning training in some form to students.

Theoretically the team signatory code aligns with the guidelines of the CEM in a number of ways. As each student is held responsible for their own actions and the consequences of their inaction, it increases the evaluation potential of the individual. Deadlines are set and signed off on which may 
provide the immediacy needed to reduce a sense of diffusion in terms of social impact. In addition, teams are encouraged to allocate roles (minute taker, leader etc.) within a team and specify these on the team signatory code which decreases their sense of dispensability. Lastly members need to discuss and decide on the specifics of a team signatory code contract and sign it. This improves the communication within the team itself, an element which has a significant relationship on inculcating trust and respect. For the purposes of this study, the level of collective effort invested in the creation of the team signatory code will be measured and analysed. It is expected that high collective effort with the team signatory code will be a positive indicator of overall team performance at the final point of the module. Specifically, it is believed that by properly engaging with the task of creating a team signatory code, a group will delve conscientiously into the group norming stages and address many of the elements outlined as advantageous in the CEM. Thus it is hypothesised that the collective effort invested in the creation of this team signatory code will be a good indication of the level of effort the team will devote to their new venture assignments. With this in mind we would propose that the level of collective effort should therefore relate to the performance of the team.

H1. There is a positive relationship between collective effort in creation of the team signatory code and final team performance.

Taken in this sense, the collective effort as measured by the creation of the team signatory code could be used by instructors as an early indicator of poor team effectiveness, allowing time for him/her to step in and remedy the problem before it results in poor performance. The signatory code acts as a deterrent to social loafing as it enables students to be aware of the consequences of their actions, and also acts as a clear unambiguous guideline for dealing with any team issues. Oakley, Hanna, Kuzmyn \& Felder (2007) found that this clause had the highest association with student satisfaction of all the instructor-controlled factors within a teamwork context. By delineating the evaluation potential for each member at the outset and allowing them to see the individual outcomes/consequences inherent in the group performance setting. In this manner we propose that should a team invest enough time and collective effort on the creation of the team signatory code then they will encounter a reduced rate of social loafing. Thus it is hypothesised that the collective effort invested in the creation of this team 
signatory code will be a good indication of the future likelihood of social loafing and disengagement with the team goals. In addition, a poorly designed team signatory code will make it more challenging for teams to deal with any free-riding in any comprehensive manner, making it more likely to occur.

H2. There is a negative relationship between collective effort in creation of the team signatory code and social loafing.

\subsection{Methodology}

\subsection{Context and participants}

Cross sectional data was used for this study, collated over a period of three years from an enterprise education module. Named digital, innovation, creativity and enterprise (DICE), the undergraduate first year module allows students to build student awareness of enterprise and innovation using real projects and role models. In the past, DICE teams have engaged in projects such as the development of a functional and downloadable mobile application for promoting tourism. The conferences with industry leaders are also attended by the students highlighting the shared purpose of these subjects. Within the module, the major assignment relates to the development of a new venture concept. Data was collected from this module over a three year period $(2009,2011$, and 2012) which amounted to232 teams in total ${ }^{1}$. The majority of teams were in groups of four or five and students had no prior teamwork experience of one another. At the start of the semester, students were taught about teamwork and the challenges that may ensue when working together. They were provided with basic templates of signatory codes which they were strongly advised to adapt. In 2013 an additional sample of 37 postgraduate student teams taking an entrepreneurship education module were added to the sample. The module, named next generation management (NGM) is a year-long module for postgraduate business students who engage in reflective and critical thinking, collaborating with companies and teams, creating and sharing knowledge, and relating to the development of new venture ideas or product/service innovation. These postgraduate teams were also monitored by the 
same academic staff as the undergraduate cohort and were instructed to create the team signatory code at the outset of their module.

\subsection{Measurement}

\section{Team Performance and Social Loafing}

Instructor reports provided the researchers with the grade each team received for their major assignment. Mean performance was recorded as $63.11 \%$ for the undergraduate class and $60.57 \%$ for the postgraduate class. Student teams were additionally asked to fill in a report at the conclusion of the module in which they were asked to stipulate any major incidences of social loafing they had witnessed in their team. Of the sample, a large number of teams reported some level of experienced social loafing in the undergraduate class ( $42.2 \%$ or 98 teams) while only 7 of the 37 teams reported social loafing in the postgraduate module (24.3\%). This is supported by theory as it is thought that the age and maturity of the participants may have a bearing on their reactions to the variables in question (Karau \& Williams 1993).

\section{Collective Effort}

In order to gauge the collective effort invested in the creation of the team signatory code, a rationale was developed by a panel of academics working in the area of student engagement. In some studies, students are asked to self-report their perception of the signatory codes however Bailey et al. (2005) found this may not have been accurate in their study (self-serving bias), as individuals were more inclined to attribute more of the time spent on projects to themselves rather than the team. The decision was made to evaluate the team signatory code artefact itself to gauge collective effort, i.e. by comparing the team signatory codes created by each team. Once all were submitted, the documents were analysed and a scoring system was devised to reflect what was considered the teams' collective effort in the completion of the task. To do so, a panel of lecturers familiar with teamwork and the team signatory code were asked to formulate a list of the most relevant points that should be included.

The list consisted of ten key points including clauses to deal with plagiarism, missed meetings, 
problem solving, maintaining a positive team atmosphere and the division of work. The team signatory codes were rated out of ten in line with these key aspects.

\subsection{Results}

The relationships between the variables for the cohorts were firstly examined using Pearson productmovement correlations (see Table 3.0). In both the undergraduate and postgraduate sample, the collective effort in the creation of the team signatory code was found to be significantly and positively related to performance. Social loafing was seen to correlate differently between the class groups however; correlating negatively with the collective effort variable for the undergraduate cohort, and negatively with the performance variable in the postgraduate cohort. Team size did not yield any significant results in either sample.

\begin{tabular}{|c|c|c|c|c|c|c|c|c|c|c|c|c|}
\hline & \multicolumn{6}{|c|}{ Undergraduate } & \multicolumn{6}{|c|}{ Postgraduate } \\
\hline & $\mathrm{N}$ & M & $\mathrm{SD}$ & 1 & 2 & 3 & $\mathrm{~N}$ & M & SD & 1 & 2 & 3 \\
\hline 1. Team Performance & 232 & 63.11 & 9.57 & - & & . & 37 & 60.57 & 5.89 & - & & \\
\hline 2. $\mathrm{CE}$ of TSC & 232 & 5.52 & 1.84 & $.184 * *$ & - & . & 37 & 5.16 & 1.28 & $.400 * *$ & - & \\
\hline 3. Social Loafing & 231 & 1.17 & 1.59 & .012 & $-.136 *$ & - & 37 & .324 & .669 & $-.584 * *$ & -.23 & - \\
\hline \multicolumn{13}{|c|}{ ** Pearson correlation is significant at the 0.01 level (2-tailed). } \\
\hline
\end{tabular}

\section{Table 3.0 Means, Standard Deviations and Intercorrelations}

Standard regression analyses were conducted to assess whether the variables relating to the teams' collective effort and social loafing would predict team performance. Preliminary analyses of the sample were conducted to ensure no violation of the assumptions of normality, linearity, multicollinearity and homoscedasity had occurred. Standard regression analysis was carried out on both the undergraduate and postgraduate groups. For the postgraduate sample, the model tested explained an adjusted $38.3 \%$ of the total variance in performance $F(3,33)=12.18, p<0.0005$ however these results must be questioned due to the small sample size used. Within this postgraduate 
model, both variables showed a uniquely significant contribution. The social loafing variable indicated a beta value of $-0.521(\mathrm{p}<.0005)$, contributing $25.7 \%$ to the explanation of variance in the performance scores of the postgraduate teams. The collective effort variable also contributes significantly with a beta value of $0.283, \mathrm{p}=0.043$. The engagement TSC variable accounts for $7.61 \%$ of variance in the model.

\begin{tabular}{lcccccc}
\hline & \multicolumn{3}{c}{ Undergraduate } & \multicolumn{3}{c}{ Postgraduate } \\
\hline & $B$ & SE B & $\beta$ & $B$ & SE B & $\beta$ \\
\hline Collective Effort (TSC) & .995 & .348 & $.191^{*}$ & 1.30 & .618 & $.283^{*}$ \\
Social Loafing & .291 & .403 & .048 & -4.58 & 1.18 & - \\
$R^{2}$ & & .036 & & & .417 & $.521^{* *}$ \\
Adjusted $R^{2}$ & & .028 & & & .383 & \\
$F$ & & $4.14^{*}$ & & & $12.18^{* *}$ & \\
Notes: $n=41$ teams.*p<0.05; & & & & & & \\
$* * p<0.01$ & & & & & & \\
\hline
\end{tabular}

Table 4.0 Simple Regression Analysis Predicting Performance

The undergraduate model explained an adjusted $2.8 \%$ of the total variance in performance, $\mathrm{F}(3,216)$ $=4.14 \mathrm{p}=0.017$, though while significant is quite a low figure. Only one of the variables (collective effort) shows a uniquely significant contribution to the model with a beta value of $0.191, \mathrm{p}=0.005$. The second hypothesis aims to find a relationship between collective effort in the creation of the team signatory code and reduced social loafing. Standard regression analysis was again conducted to assess whether the collective effort variable related to social loafing. For the postgraduate sample, the model was not supported, likely due to the small sample size. The undergraduate model attained a significant but distinctly low relationship with an adjusted $1.4 \%$ of the total variance in social loafing $\mathrm{F}(3,222)$ $=4.17, \mathrm{p}=0.42$. The collective effort variable indicated a beta value of $-0.136(\mathrm{p}<.05)$.

\subsection{Discussion}

This research study aimed to examine student teams within the context of entrepreneurship education at university level. The study particularly focused on the team problem of social loafing, a phenomenon whereby students fail to contribute fairly in team activities (Aggarwal \& O'Brien 2008). Social loafing was discussed using the collective effort model as the theoretical model (Karau and 
Williams, 2001; 1993). It was proposed that the use of the team signatory code could assist to facilitate teamwork on two levels; firstly by acting as an early development tool for teams during their norming stages of functioning, and secondly as an early-warning system for educators to detect poorly developing teams. Specifically it was hypothesised that the effort of the team (or collective effort) invested in the creation of the signatory code would be a predictor of performance, and of social loafing.

Teams in an entrepreneurship education module were assessed in terms of their collective effort in the creation of a team signatory code, team performance and the instances of social loafing that they encountered over the course of a module in entrepreneurship education. A sample of 232 undergraduate and 37 postgraduate teams was obtained and analysed on a number of levels, including a comparison of undergraduate and postgraduate teams. In the first instance it was observed using Pearson product-movement correlations that performance was positively and significantly correlated to collective effort in both the undergraduate and postgraduate samples. Extending this it was observed in the regression analysis that for the both sample groups, collective effort was seen to significantly predict team performance. Thus, the first hypothesis is supported, suggesting that the collective effort invested in the creation of the team signatory code could be used to predict the variance in performance to an extent. In terms of social loafing, there was a difference noted in the findings between undergraduate and postgraduate team level. For the postgraduate group, though there was a sample size limitation, results indicated a negative relationship between performance and social loafing. Using regression analyses, it was observed that social loafing was seen to predict the variance in performance in the postgraduate sample. Social loafing did not have a significant relationship with performance in the undergraduate class group, even despite the fact that it was a more prevalent problem witnessed in teams $(42.2 \%$ or 98 teams reporting some form of social loafing within their team). This may be an indication that there may be more students willing to act as the 'diligent isolate' at this level, and do more than their fair share to prevent overall poor team performance. 
The second hypothesis aimed to find a relationship between collective effort in the creation of the team signatory code and social loafing. It was observed that there was a significantly negative relationship between the two variables, and that collective effort was found to be a weak but significant predictor of social loafing during the year for the undergraduate student teams.

\subsection{Conclusions and Future Research}

Understanding and improving upon pedagogical (and andragogical) practices used to deliver entrepreneurship education is crucial to the subjects sustainability. Team entrepreneurship is becoming a more considered area of research, exemplified by the recent Journal of Management literature review documenting 42 articles in the area (Klotz et al., 2014). In addition, teamwork is listed in most EEP competency frameworks and government publications (Draycott \& Rae 2011). However research into student team entrepreneurship is lacking and requires more explicit guidelines to support in-class innovation. The pedagogy employed in entrepreneurship education is widely disparate and in the eyes of Rideout and Gray (2013) is driven by tradition and general educational norms rather than research-based theory. Indeed, as yet it has not been confirmed that teamwork is even a positive practice in entrepreneurship education, with the recent work of Canziani et al. (2015) finding negative effects on students in this context. Thus, this research paper aims to examine the team in this context and calls for more in-depth research to ascertain whether the assumption that teamwork in entrepreneurship education is beneficial to students, is actually true. Rather than grouping students into teams to reduce an instructors workload (Pfaff \& Huddleston 2003), the decision to engage in team enterprise initiatives should be based on the desire to provide an effective and innovative learning experience

It is clear from this study that social loafing is a very real problem in entrepreneurship education teams, and our findings indicate that in some circumstances this has a bearing on their team performance. The empirical study suggests relationships between the effort invested in the creation of the signatory code at the start of the year and two outcome variables, performance and social loafing. It could be speculated that the effort invested by a team is representative of their effort in any or all team assignments, thus would logically be connected to the two outcome variables. This is not 
disputed by the authors, and instead it is proposed that the use of the team signatory code has a dual purpose. It firstly attempts to allow students to evaluate and recognise their own value, instrumentality and expectancy within a team, thus helping to prevent social loafing as it has been seen to do in other contexts (Hunsaker et al. 2011; Cox \& Bobrowski 2000). However we propose a second benefit of the creation of the team signatory code. Our evaluation of the comprehensiveness of these team signatory code documents, documents which were created at the early stages of the year, was seen to predict levels of performance and social loafing months later. Thus we propose that this practice be used as an early detection tool for poorly performing teams. Once the teams submit their team signatory codes, instructors could review each teams' collective effort in devising them, and subsequently locate teams which may have low performance or high social loafing in the future. It would be recommended that these teams be given additional teamwork development supports such as training or enhanced supervision.

\section{Limitations and future research}

There are a number of areas which could have been improved upon in the research study outlined. As outlined previously, the empirical study was weakened due to the small sample size of the postgraduate group, and also the weak relationships noted in the regression analyses of the undergraduate group. To extend this study it is hoped to increase the number of teams studied and use another sample group as a control. In addition, differing statistical analyses such as path analyses and structural equation models may give deeper insight into the relationships introduced during this study.

Further work is to be carried out on this sample exploring the individual-level factors that affect these constructs. In particular, work is being undertaken to explore the difference that occurs when groups are made up of students possessing varying levels of entrepreneurial intention and entrepreneurial passion. It is not well known how teams which contain aspiring entrepreneurs react in terms of social loafing. On the one hand, an enterprising individual may take the lead and inspire his teammates to devote much time and effort into a project thus eliminating social loafing. Alternatively, a student that is enterprising may monopolize the project acting as thus forcing teammates to take lesser roles and increasing the potential for loafing. These areas were not explored in this research 
study and may lead to valuable insights for team construction in enterprise modules. Wing Yan Man (2015) noted that teams in entrepreneurship education offer an interesting research perspective as they allow for an array of social interactions with multiple stakeholders (teammates, mentors, clients, business people etc.). There are many research avenues which could be explored within the area of student team entrepreneurship and we welcome further enquiry in all aspects.

\subsection{Bibliography}

Aggarwal, P. \& O’Brien, C.L., 2008. Social Loafing on Group Projects: Structural Antecedents and Effect on Student Satisfaction. Journal of Marketing Education, 30(3), pp.255-264.

Antoni, C. \& Hertel, G., 2009. Team processes, their antecedents and consequences: Implications for different types of teamwork. European Journal of Work and Organizational Psychology, 18(3), pp.253-266.

Bailey, J. et al., 2005. Teaching with and through Teams: Student-Written, Instructor-Facilitated Case Writing and the Signatory Code. Journal of Management Education, 29(1), pp.39-59.

Baldwin, T.T., Bedell, M.D. \& Johnson, J.L., 1997. The social fabric of a team-based M.B.A. program: Network effects on student satisfaction and performance. Academy of Management Journal, 40, pp.1369-1397.

Beal, D.J. et al., 2003. Cohesion and performance in groups: a meta-analytic clarification of construct relations. The Journal of Applied Psychology, 88(6), pp.989-1004.

Burdett, J., 2003. Making Groups Work: University Students' Perceptions. International Education Journal, 4(3), pp.177-191.

Canziani, B. et al., 2015. What Pedagogical Methods Impact Students' Entrepreneurial Propensity? Journal of Small Business Strategy, 25(2), pp.97-113.

Carey, C. \& Matlay, H., 2011. Emergent issues in enterprise education: the educator's perspective. Industry Higher Education, 25, pp.441-450. 
Chidambaram, L. \& Tung, L.L., 2005. Is Out of Sight, Out of Mind? An Empirical Study of Social Loafing in Technology-Supported Groups. Information Systems Research, 16(2), pp.149-168.

Cook, L., 1991. Cooperative learning: A successful college teaching strategy. Innovative Higher Education, 16(1), pp.27-38.

Cox, P.L. et al., 2005. Enhancing the First-Year Experience for Business Students: Student Retention and Academic Success. Journal of Behavioral \& Applied Management, 7(1), pp.40-68.

Cox, P.L. \& Bobrowski, P.E., 2000. The Team Charter Assignment: Improving The Effectiveness of Classroom Teams. Journal of Behavioral and Applied Management, 1(1), pp.92-103.

Deeter-Schmelz, D.R., Kennedy, K.N. \& Ramsey, R.P., 2002. Enriching Our Understanding of Student Team Effectiveness. Journal of Marketing Education, 24(2), pp.114-124.

Dommeyer, C.J., 2007. Using the Diary Method to Deal With Social Loafers on the Group Project: Its Effects on Peer Evaluations, Group Behavior, and Attitudes. Journal of Marketing Education, 29(2), pp.175-188.

Draycott, M. \& Rae, D., 2011. Enterprise education in schools and the role of competency frameworks. International Journal of Entrepreneurial Behaviour \& Research, 17(2), pp.127-145.

Druskat, V.U. \& Kayes, D.C., 2000. Learning versus performance in short-term project teams. Small Group Research, 31, pp.328-353.

Dunne, E. \& Rawlins, M., 2000. Bridging the Gap Between Industry and Higher Education: Training Academics to Promote Student Teamwork. Innovations in Education \& Training International, 37(4), pp.361-371.

English, A., Griffith, R.L. \& Steelman, L.A., 2004. Team Performance: The Effect of Team Conscientiousness and Task Type. Small Group Research, 35(6), pp.643-665.

Eva, K.W., 2002. Teamwork during education: the whole is not always greater than the sum of the parts. Medical Education, 36(4), pp.314-316. 
Fayolle, A., Gailly, B. \& Lassas-Clerc, N., 2006. Assessing the impact of entrepreneurship education programmes: a new methodology. Journal of European Industrial Training, 30(9), pp.701-720.

Fiet, J.O., 2001. The pedagogical side of entrepreneurship theory. Journal of Business Venturing, 16(2), pp.101-117.

Fleming, P., 1999. Developing graduate entrepreneurs : an analysis of entrepreneurship education programmes in Ireland. Durham University.

Gagne, M. \& Zuckerman, M., 1999. Performance and Learning Goal Orientations as Moderators of Social Loafing and Social Facilitation. Small Group Research, 30(5), pp.524-541.

Gillies, R.M., 2004. The effects of cooperative learning on junior high school students during small group learning. Learning and Instruction, 14(2), pp.197-213.

Gokhale, A.A., 1995. Collaborative Learning Enhances Critical Thinking. Journal of Technology education, 7(1), pp.22-30.

Hamidi, Y., Wennberg, K. \& Berglund, H., 2008. Creativity in entrepreneurship education. Journal of Small Business and Enterprise Development, 15(2), pp.304-320.

Hansen, R.S., 2006. Benefits and Problems With Student Teams: Suggestions for Improving Team Projects. Journal of Education for Business, 82(1), pp.11-19.

Hardy, C.J. \& Crace, R.K., 1997. Foundations of Team Building: Introduction to the Team Building primer. Journal of Applied Sport Psychology, 9(1), pp.1-10.

Harkins, S.G. \& Petty, R.E., 1982. Effects of task difficulty and task uniqueness on social loafing. Journal of Personality and Social Psychology, 43(6), pp.1214-1229.

Harkins, S.G. \& Szymanski, K., 1989. Social loafing and group evaluation. Journal of Personality and Social Psychology, 56(6), pp.934-941. 
Harms, R., 2015. Self-regulated learning, team learning and project performance in entrepreneurship education: Learning in a lean startup environment. Technological Forecasting and Social Change.

Heinonen, J. \& Poikkijoki, S.-A., 2006. An entrepreneurial-directed approach to entrepreneurship education: mission impossible? Journal of Management Development, 25(1), pp.80-94.

Hernandez, S.A., 2002. Team Learning in a Marketing Principles Course: Cooperative Structures That Facilitate Active Learning and Higher Level Thinking. Journal of Marketing Education, 24(1), pp.7385.

Hill, A.D. et al., 2013. Innovation and Effectiveness of Co-Founded Ventures: A Process Model. Journal of Business and Psychology, 29(1), pp.145-159.

Holtham, C.W., Melville, R.R. \& ManMohan, S.S., 2006. Designing student groupwork in management education: Widening the palette of options. Journal of Management Education, 30(6), pp.809-817.

Hunsaker, P., Pavett, C. \& Hunsaker, J., 2011. Increasing Student-Learning Team Effectiveness With Team Charters. Journal of Education for Business, 86(3), pp.127-139.

Hynes, B., 1996. Entrepreneurship education and training - introducing entrepreneurship into nonbusiness disciplines. Journal of European Industrial Training, 20(8), pp.10-17.

Hytti, U. et al., 2010. Perceived learning outcomes in entrepreneurship education: The impact of student motivation and team behaviour. Education + Training, 52(8/9), pp.587-606.

Hytti, U. \& O'Gorman, C., 2004. What is “enterprise education"? An analysis of the objectives and methods of enterprise education programmes in four European countries. Education + Training, 46(1), pp.11-23.

Jackson, J.M. \& Harkins, S.G., 1985. Equity in effort: an explanation of the social loafing effect. Journal of Personality and Social Psychology, (49), pp.1199-1206. 
Jassawalla, A., Sashittal, H. \& Sashittal, A., 2009. Students' Perceptions of Social Loafing: Its Antecedents and Consequences in Undergraduate Business Classroom Teams. Academy of Management Learning \& Education, 8(1), pp.42-54.

Johnson, D.W. \& Johnson, R.T., 1989. Cooperation and Competition Theory and Research, Minnesota, USA: Interaction Book Company.

Johnson, D.W., Johnson, R.T. \& Stanne, M.B., 2000. Cooperative Learning Methods: A MetaAnalysis, Minneapolis, MN: University of Minnesota.

Jones, C., 2006. Enterprise education: revisiting Whitehead to satisfy Gibbs. Education + Training, 48(5), pp.356-367. Available at: http://www.emeraldinsight.com/journals.htm?articleid=1562337 [Accessed August 29, 2011].

Karau, S.J., 1993. Social loafing: A meta-analytic review and theoretical integration. Journal of Personality and Social Psychology, 65(4).

Karau, S.J. \& Kipling D. Williams, 2001. Understanding individual motivation in groups: The collective effort model. In Groups at work: Theory and Research. pp. 113-141.

Karau, S.J. \& Williams, K.D., 1993. Social loafing: A meta-analytic review and theoretical integration. Journal of Personality and Social Psychology, 65(4), pp.681-706.

Karau, S.J. \& Williams, K.D., 1995. Social loafing: Research findings, implications, and future directions. Current Directions in Psychological Science, 45(5), pp.134-140.

Kerr, N.L., 1983. Motivation losses in small groups: A social dilemma analysis. Journal of Personality and Social Psychology, 45(4), pp.819-828.

Laal, M. \& Ghodsi, S.M., 2012. Benefits of Collaborative Learning. Social and Behavioural Sciences, 31, pp.486-490.

Latané, B., 1981. The psychology of social impact. American Psychologist, 36(4), pp.343-356. 
Latané, B., Williams, K. \& Harkins, S., 1979. Many hands make light the work: The causes and consequences of social loafing. Journal of Personality and Social Psychology, 37(6), pp.822-832.

Lewis K. \& Massey C., 2003. Delivering enterprise education in New Zealand. Education and Training, 45(4), pp.197-206.

Lüthje, C. \& Prügl, R., 2006. Preparing business students for co-operation in multi-disciplinary new venture teams: empirical insights from a business-planning course. Technovation, 26(2), pp.211-219.

McMullen, J.S. \& Shepherd, D.A., 2006. Entrepreneurial action and the role of uncertainty in the theory of the entrepreneur. Academy of Management Review, 31(1), pp.132-152.

Mojab, F., Zaefarian, R. \& Azizi, A.H.D., 2011. Applying Competency based Approach for Entrepreneurship education. Procedia - Social and Behavioral Sciences, 12, pp.436-447.

Mulvey, P.W. \& Klein, H.J., 1998. The Impact of Perceived Loafing and Collective Efficacy on Group Goal Processes and Group Performance. Organizational Behavior and Human Decision Processes, 74(1), pp.62-87.

North, A.C., Linley, P.A. \& Hargreaves, D.J., 2000. Social Loafing in a Co-operative Classroom Task. Educational Psychology, 20(4), pp.389-392.

Nowak, L.I., Miller, S.W. \& Washburn, J.H., 1996. Team Testing Increases Performance. Journal of Education for Business, 71(5), pp.253-256.

O’Connor, J., Fenton, M. \& Barry, A., 2012. Entrepreneurship education: Ireland's solution to economic regeneration? Industry and Higher Education, 26(3), pp.241-249.

Oakley, B. et al., 2004. Turning Student Groups into Effective Teams. Journal of Student Centered Learning, 2(1), pp.9-22.

Oakley, B.A. et al., 2007. Best Practices Involving Teamwork in the Classroom: Results From a Survey of 6435 Engineering Student Respondents. IEEE Transactions on Education, 50(3), pp.266272. 
Panitz, T., 1999. The Motivational Benefits of Cooperative Learning. New Directions for Teaching and Learning, 1999(78), pp.59-67.

Pfaff, E. \& Huddleston, P., 2003. Does It Matter if I Hate Teamwork? What Impacts Student Attitudes toward Teamwork. Journal of Marketing Education, 25(1), pp.37-45.

Pieterse, V. \& Thompson, L., 2010. Academic alignment to reduce the presence of "social loafers" and "diligent isolates" in student teams. Teaching in Higher Education, 15(4), pp.355-367.

Qin, Z., Johnson, D.W. \& Johnson, R.T., 1995. Cooperative Versus Competitive Efforts and Problem Solving. Review of Educational Research, 65(2), pp.129-143.

Rae, D., 2007. Connecting enterprise and graduate employability: Challenges to the higher education culture and curriculum? Education + Training, 49(8/9), pp.605-619.

Rasmussen, E. \& Sørheim, R., 2006. Action-based entrepreneurship education. Technovation, 26(2), pp.185-194.

Rideout, E.C. \& Gray, D.O., 2013. Does Entrepreneurship Education Really Work? A Review and Methodological Critique of the Empirical Literature on the Effects of University-Based Entrepreneurship Education. Journal of Small Business Management, 51(3), pp.329-351.

Rutte, C.G., 2005. Social Loafing in Teams. In M. A. West, D. Tjosvold, \& K. G. Smith, eds. The Essentials of Teamworking: International Perspective. John Wiley \& Sons, Ltd., pp. 191-207.

Salas, E. et al., 1992. Toward an understanding of team performance and training. In Teams: Their training and performance. Westport, US: Ablex Publishing.

Sanna, L.J., 1992. Self-efficacy theory: Implications for social facilitation and social loafing. Journal of Personality and Social Psychology, 62(5), pp.774-786.

Schippers, M.C., 2014. Social Loafing Tendencies and Team Performance: The Compensating Effect of Agreeableness and Conscientiousness. Academy of Management Learning \& Education, 13(1), pp.62-81. 
Smith, B.N. et al., 2001. Individual differences in social loafing: Need for cognition as a motivator in collective performance. Group Dynamics: Theory, Research, and Practice, 5(2), pp.150-158.

Solomon, G.T., Weaver, K.M. \& Fernald, L.W., 1994. A Historical Examination of Small Business Management and Entrepreneurship Pedagogy. Simulation \& Gaming, 25, pp.338-352.

Steinbrink, J.E. \& Jones, R.M., 1993. Cooperative Test-Review Teams Improve Student Achievement. The Clearing House, 66(5), pp.307-311.

Steiner, 1972. Group Processes and Productivity, San Diego: Academic Press.

Terenzini, P. et al., 2001. Collaborative Learning vs. Lecture/Discussion: Students' Reported Learning Gains. Journal of Engineering Education, 90(1), pp-123-130.

Valenti, A. et al., 2005. Tools for managing teams. Southwestern Business Administration Journal, $5(1)$.

Veenman, S. et al., 2002. Cooperative learning and teacher education. Teaching and Teacher Education, 18(1), pp.87-103.

Vroom, V.H., 1964. Work and Motivation, New York: Wiley.

Weldon, E. \& Mustari, E.L., 1988. Felt dispensability in groups of coactors: The effects of shared responsibility and explicit anonymity on cognitive effort. Organizational Behavior and Human Decision Processes, 41(3), pp.330-351.

Wheelan, S.A., 2009. Group Size, Group Development, and Group Productivity. Small Group Research, 40(2), pp.247-262.

Williams, K., Harkins, S.G. \& Latané, B., 1981. Identifiability as a deterrant to social loafing: Two cheering experiments. Journal of Personality and Social Psychology, 40(2), pp.303-311.

Wing Yan Man, T., 2015. Psychological ownership in team-based entrepreneurship education activities. International Journal of Entrepreneurial Behaviour \& Research, 21(4), pp.600-621. 
Woodcock, M. \& Francis, D., 1981. Organisation development through teambuilding: Planning a cost effective strategy, New York: Wiley. 
